\title{
Assessing endangerment of archaeological heritage in Latvia: legal framework and socio-economic aspects
}

\author{
Andris KAIRISS \\ Riga Technical University \\ kairiss.andris@gmail.com \\ Irina OLEVSKA \\ ArtLaw.club \\ irina@artlaw.club
}

\section{ABSTRACT}

The aim of the article is to reflect the currently existing regulatory environment for damages caused to archaeological sites by illegal human intervention and its implementation by law enforcement sector and the courts in Latvia. The article is mostly focused on legal and socio-economic consequences of endangerment of archaeological sites. It analyses liability aspects, examines case law, determines the existing challenges and proposes basis for improvement in administrative and legal procedures. Methods applied in the research are literature review, legal framework and documentary analysis, statistical and case law analysis. The results of the research could be used inter alia for the purposes of criminal, civil and administrative proceedings, amending legal regulation and damage assessment mechanisms.

\section{KEYWORDS}

Archaeological heritage; cultural heritage; cultural monuments; damage assessment; liability; looting; socio-economic benefits

AP: Online Journal in Public Archaeology - Volume 11 - ISSN: 2171-6315

Kairiss, A. \& Olevska, I. 2021. Assessing endangerment of archaeological heritage in Latvia: legal framework and socio-economic aspects. AP: Online Journal in Public Archaeology 11, a39-a72.

DOI: $10.23914 / a p . v 11 i 0.281$

Received: 14/10/2020 :: Accepted: 05/01/2021 


\section{a40 :: AP Journal v.11 :: ARTICLE}

\section{General description of the situation in Latvia}

Latvia is a small country in North-Eastern Europe, in the Baltic Sea region. Despite its modest size, Latvia can be proud of its rich history and, as a testament to this, also many archaeological monuments, a large number of which date back to the Viking and Crusader eras.

As of 1 September 2020, according to the information from the SPCMR there were 7361 immovable cultural monuments in Latvia, with 2520 (or 34\%) of these immovable monuments being archaeological. ${ }^{2}$ Archaeological monuments mainly include ancient burial sites (1246), hillforts (479), settlements (236), and cult places (168).

A large number of archaeological monuments, especially ancient burial grounds, due to their location in less populated areas, combined with their insufficient protection ${ }^{3}$ have been the focus of activities targeting the illegal acquisition of antiquities. As a result of these activities, particularly in the period from 2012 to 2016, a significant amount of Viking-era antiquities of Latvian origin entered the illegal market on online trading platforms (IR, 2006).

In 2015-2016, with the development of preventive measures ${ }^{4}$ and the training of staff of controlling institutions, increased activity of the NCHB and the State Police, and initiation of work on improvement of the regulatory framework, the situation started to improve. The number of offences against the archaeological heritage decreased, and the number of illegally traded antiquities of Latvian origin also decreased significantly. At the same time, despite the progress in the improvement of the regulatory framework, difficulties were identified in the implementation of the relevant legal norms in practice, which was primarily related to the complexity of proof of certain illegal actions and lack of methodology for objective determination of losses and damages (Kairiss, Olevska, 2020; Kairiss, 2017; SP Interview, PO Interview).

In the first half of 2020, more cases of damage caused to archaeological monuments were registered in Latvia than in 2019, which indirectly indicated the performance of illegal activities, most likely due to the COVID-19 pandemic. At

\footnotetext{
1 According to Section 12, Protection Law, the SPCMR is maintained and updated by the NCHB $21508(60 \%)$ of the archaeological monuments are of state significance, while $1012(40 \%)$ monuments are of local significance. According to the Protection Law, state significance status may be granted to objects of national or international significance with outstanding scientific, cultural and historical, or educating significance. Local significance status (based on the amendments to the Protection Law as of 2018, local significance status has been divided into regional and local significance) is granted to objects with a special scientific, cultural and historical, or educating significance characteristic to a particular region or territory. The entries in the SPCMR have not yet been updated to reflect the mentioned amendments.

3 Lack of administrative capacity has been manifold, as mentioned in the ARs of the NCHB (AR 2018, AR 2017, AR 2016)

4 For example, by developing and distributing the Catalogue of Endangered Latvian Archaeological Artefacts
} 
the broader level, the focus on sanitary measures and restriction of movement reduced the surveillance of cultural sites and museums, leading, in turn, to an increase in illegal excavations of archaeological sites and trafficking activities, including online transactions (UNESCO, 2020). A dangerous trend was also identified by the NCHB, which published relevant warning information (NCHB, 2020).

The aim of this article is to provide an insight into the Latvian regulatory framework and undertaking of criminal proceedings in relation to offences in the field of archaeological heritage, as well as to look at the assessment of damage caused by such offences in both legal and socio-economic contexts. The study makes use of thematic literature, the legal framework, criminal cases, documentary and statistical analysis, as well as interview materials.

\section{Legal framework}

According to the current legal regime in Latvia, different illegal actions causing damage to cultural monuments can be subject to civil, administrative or criminal liability.

\section{Civil liability}

The umbrella substantive law for torts and civil disputes in Latvia is Civil Law. According to it, the compensation of losses to the victim is the main civil remedy available for the consequences of infringement. Its purpose is to ensure that the situation which would have existed in the absence of the infringement has been restored as fully as possible (Torgāns, 2006). If a person suffers losses from the illegal actions of another person outside the scope of contractual relations (e.g., as a result of a tort), the person causing the losses shall be liable for all losses, ${ }^{5}$ which may be direct, indirect and/or accidental. ${ }^{6}$ Those losses, which have already arisen, may be in a form of diminution of the victim's present property or a decrease in his or her anticipated profits?.

Reference to civil procedure is also provided for in special legislation directly applicable to cultural monuments. Thus, Cabinet Regulation $474^{8}$ states that a person who has caused damages to a cultural monument or has illegally modified

5 Section 1784, Civil Law

6 Section 1773, Civil Law. A loss shall be considered: direct where it is the natural and inevitable result of an illegal act or failure to act; indirect where it is caused by an occurrence of particular circumstances or relationships; and accidental where caused by a chance event or force majeure.

7 Section 1772, Civil Law; Section 1787, Civil Law, states that mere possibilities shall not be used as the basis for calculating lost profits, rather there must be no doubt, or it must at least be proven to a level that would be credible as legal evidence, that such detriment resulted, directly or indirectly [...], from the act or failure to act which caused the loss.

8 Par.59, Cabinet Regulation 474 


\section{a42 :: AP Journal v.11 :: ARTICLE}

the cultural and historical environment in the territory of the cultural monument or in the protection zone thereof shall renovate the cultural monument and the environment to the previous condition. If renovation is not possible, the person referred to shall compensate the losses in accordance with the procedures specified by the Civil Procedure Law.

Section 1792, Civil Law, in its turn, states that if a claim for compensation of losses has arisen [...] from acts which are of themselves illegal, then the loss valuation shall correspond to the value of the subject-matter at the time the loss was occasioned.

The regulation mentioned above unambiguously provides for the proper determination and precise assessment of the subject matter of the dispute (e.g., damages/losses caused to the archaeological site) in order to justify the claim for compensation of losses.

Referral to civil procedure for compensation of losses may also occur in the context of compensation requests in criminal cases. According to Criminal Procedure Law ${ }^{9}$ if a victim believes that the entire harm caused to him or her has not been compensated with a compensation within the criminal proceedings, he or she has the right to request the compensation thereof in accordance with the procedures laid down in the Civil Procedure Law. In determining the amount of consideration (which is to be precisely assessed and justified), the compensation received in criminal proceedings shall be taken into account. ${ }^{10}$

No statistical information is available about the compensation requests (their volume and money judgments) made within or outside of criminal proceedings regarding the damages caused to archaeological sites by illegal actions of third parties. Similarly, no statistics are being gathered on whether and in which cases there are persons, other that the State, recognized as aggrieved parties in the respective cases (CA Information). However, according to the information provided by the State Police, there have been no cases in which the owner of the archaeological site, other than the State (whether it be the municipality or a private person) has ever submitted a request for compensation of damages caused to the site by the illegal actions of third parties within the criminal procedure (SP Interview). Consequently, there have been no cases of this kind where compensation had been requested within the civil procedure according to the section mentioned above. ${ }^{11}$

\footnotetext{
9 Section 350, Criminal Procedure Law
}

10 Section 350, Criminal Procedure Law

11 According to Section 24 of the Protection Law, conservation, maintenance, renovation and restoration of a cultural monument shall be performed by the owner (possessor) of the cultural monument at his or her own expense. If the owner for any reason has not requested/received a monetary judgment for conservation of the damaged cultural monuments from the offender, the Protection Law provides for allocation of State/municipal 
:: Kairiss \& Olevska - Assessing endangerment of archaeological... :: a43

\section{Administrative liability}

In the middle of 2020, the Latvian administrative system underwent substantial changes. On 1 July 2020, the Administrative Violations Code, in force since July 1985, ${ }^{12}$ was replaced by the Law on Administrative Liability. Based on the latter, the Protection Law was supplemented by the new chapter on Administrative Violations in the Field of Protection of Cultural Monuments and Competence in the Process of Administrative Violations, ${ }^{13}$ with certain changes transposing administrative violations in the field of cultural monuments into the Protection Law.

Corresponding norms related to offences against (i.e. causing damages to) cultural monuments are presented in Table 1:

Table 1. Transposition of administrative violations' norms

\begin{tabular}{|c|c|c|c|}
\hline \multicolumn{2}{|c|}{$\begin{array}{l}\text { Latvian Administrative Violations Code } \\
\text { (in force until 1 July 2020) }\end{array}$} & \multicolumn{2}{|c|}{$\begin{array}{l}\text { Law on Protection of Cultural Monuments } \\
\text { (Chapter } 7 \text {, in force as of } 1 \text { July 2020) }\end{array}$} \\
\hline Section ${ }^{14}$ & Sanction & Section & Sanction ${ }^{15}$ \\
\hline $\begin{array}{l}\text { Section } 89 \text {. Violation } \\
\text { of the rules for the } \\
\text { protection of cultural } \\
\text { monuments }\end{array}$ & $\begin{array}{l}\text { Fine } \\
\text { Natural persons } \\
\text { - EUR 140-700 } \\
\text { Legal persons } \\
\text { - EUR 1100- } \\
4300\end{array}$ & $\begin{array}{l}\text { Section } 32 \text {. Violation } \\
\text { of the rules for the } \\
\text { protection of cultural } \\
\text { monuments }\end{array}$ & $\begin{array}{l}\text { Warning or fine } \\
\text { Natural persons - } \\
\text { EUR } 100-1000 \\
\text { Legal persons } \\
\text { - EUR 1000- } \\
10000\end{array}$ \\
\hline $\begin{array}{l}\text { Section } 89.1 \text { Violation } \\
\text { of the rules for the } \\
\text { restoration, conservation } \\
\text { and repair of cultural } \\
\text { monuments, as well as } \\
\text { for the performance } \\
\text { of research and } \\
\text { archaeological } \\
\text { excavations }\end{array}$ & $\begin{array}{l}\text { Fine } \\
\text { Natural persons } \\
\text { - EUR 140- } \\
5570 \\
\text { Legal persons - } \\
\text { EUR 700-1400 }\end{array}$ & $\begin{array}{l}\text { Section } 33 \text {. Violation } \\
\text { of regulations for } \\
\text { transformation, research } \\
\text { and archaeological } \\
\text { excavations of cultural } \\
\text { monuments, their } \\
\text { territories and protection } \\
\text { zones }\end{array}$ & $\begin{array}{l}\text { Warning or fine } \\
\text { Natural persons } \\
\text { EUR } 500-2000 \\
\text { Legal persons } \\
\text { - EUR 2500- } \\
20000\end{array}$ \\
\hline
\end{tabular}

budgetary funds for conservation of cultural monuments under certain (quite strict) conditions. According to the AHD Answers, JSC Latvian state forests (AS Latvijas Valsts Mežil) applied for such program funding to carry out conservation works upon the destroyed archaeological monuments. It should be noted, however, that the conservation of the destroyed monument took place more than 3 years after the destruction (LETA, 2019).

12 According to Annotation 2014, the Administrative Violations Code was amended more than 150 times from 1985. Most of the problems currently identified are due to unclear and inefficient administrative violation procedures. Therefore, the main emphasis on system reform is to create a new, clear, fast and efficient process.

13 Chapter 7, Protection Law

14 Sections 89, 89.' and 89.2 provide for basic and aggravated elements of the respective offences.

15 According to Section 16 of the Law on Administrative Liability, the amount of a fine is expressed in the units of fine, where one unit equals EUR 5 (according to the wording in force as of July 2020). The amounts of fines are provided in euros in the table for the purpose of ease of comparison. 


\begin{tabular}{|c|c|c|c|}
\hline \multicolumn{2}{|c|}{$\begin{array}{l}\text { Latvian Administrative Violations Code } \\
\text { (in force until } 1 \text { July 2020) }\end{array}$} & \multicolumn{2}{|c|}{$\begin{array}{l}\text { Law on Protection of Cultural Monuments } \\
\text { (Chapter } 7 \text {, in force as of } 1 \text { July 2020) }\end{array}$} \\
\hline Section ${ }^{14}$ & Sanction & Section & Sanction ${ }^{15}$ \\
\hline $\begin{array}{l}\text { Section } 89 .{ }^{2} \text { Damage, } \\
\text { transformation and } \\
\text { unauthorized economic } \\
\text { activity in the territories of } \\
\text { cultural monuments and } \\
\text { protection zones }\end{array}$ & $\begin{array}{l}\text { Fine } \\
\text { Natural persons } \\
\text { - EUR 70-500 } \\
\text { Legal persons - } \\
\text { EUR 350-1400 }\end{array}$ & $\begin{array}{l}\text { (in general, transposed } \\
\text { into Section 33) }\end{array}$ & - \\
\hline $\begin{array}{l}\text { Section } 89.5 \text { Damage to } \\
\text { a grave }\end{array}$ & $\begin{array}{l}\text { Fine } \\
\text { Natural persons } \\
\text { - EUR 140-570 } \\
\text { Legal persons - } \\
\text { EUR 350-1100 }\end{array}$ & Omitted & - \\
\hline
\end{tabular}

The main changes include the omission of aggravating elements in disposition of the sections (the broader scope of fines is foreseen instead of one for each individual offence). Some violations (e.g. damage to a grave) have been omitted, while others (e.g. damage, transformation and unauthorized economic activity in the territories of cultural monuments and protection zones and unauthorized performance of research and archaeological excavations) have been merged under one section. While the Latvian Administrative Violations Code provided only for fines as sanctions, now the sanctions provide for both warnings and monetary penalties (fines), with the latter being much broader in range.

Within the last 1.5 years of operation of the Latvian Administrative Violations Code (2019 and the first half of 2020), 8 administrative proceedings have been initiated, including 4 cases for damage, transformation or unauthorized economic activity in the protection zones of cultural monuments, 2 cases for the damage, transformation or unauthorized economic activity in the territories of cultural monuments, 2 cases for violation of the rules for the protection of cultural monuments, and 3 cases for violation of the rules for the protection of cultural monuments, if the cultural monument is damaged; some offences cumulatively qualified under two or more sections or parts of sections (NCHB Statistics). $\mathrm{NCHB}$ undertakes full administrative procedure, except in cases where additional investigation is needed and where State Police officers become involved.

\section{Criminal liability}

The current Criminal Law of Latvia has been in force since 1999. Certain norms have provided for criminal liability for the damage of cultural monuments from the 
:: Kairiss \& Olevska - Assessing endangerment of archaeological... :: a45

day of adoption of the law, while the others have been added through amendments. Here is the short overview of the existing legal regime, while the overall statistics on the number of criminal offences from the registration to the court's decision is provided at the end of this article.

Section 79: Liability for Destruction of Cultural and National Heritage ${ }^{16}$ was provided for in the Law from the moment of adoption, and still remains in force with no changes in disposition. The norm does not provide for any form of aggravating element. It foresees criminal liability for a person who commits intentional destruction of such values which constitute part of the cultural or national heritage. Despite the fact that over the last decade there have been no criminal offences registered that qualify under this norm (IC statistics 2011-2019), and the norm has never been analysed by the court (LSC Information), as an overall tendency, the imprisonment sanction has, over the years, been decreased from an initial 17 years (in force up to 2012) to the current 12 years of deprivation of liberty. ${ }^{17}$

Section 228, Part 3: Liability for desecration of graves and corpses, if the offence is related to stealing of a monument or funerary urn, or other object(s) placed on or in a grave or at a funerary urn, ${ }^{18}$ has also been part of the Criminal Law from the moment of adoption (this is the aggravation of basic elements of the offence by desecration of graves, funerary urns or interred or uninterred corpses). Similarly to the norm related to destruction of cultural and national heritage discussed above, there have been no changes in disposition, while the initial sanction (from 3 to 15 years with or without confiscation of property, in force up to 2013) was gradually decreased to the present-day deprivation of liberty for a period of up to 5 years or a lesser sentence with or without confiscation of property.

Until 2018, when the norm on illegal acquisition and turnover of antiquities came into force, desecration of graves related to the theft of objects was the qualification most frequently applied to the illegal obtaining of antique objects from ancient burial grounds. The norm was hard to apply, however, partially due to the impossibility of determining the offender ${ }^{19}$ and partially (in the absence of

16 Section 79, Criminal Law LV, Chapter IX, Crimes against Humanity and Peace, War Crimes and Genocide 17 Part 6, Section 7 of the Criminal Law provides that if the deprivation of liberty for a period not exceeding five years is foreseen for a crime, also a type of lesser punishment may be provided for therein for the relevant crime. This means that, for those crimes where sanctions provide for imprisonment exceeding 5 years, no alternative basic punishments - community service or a fine - can be applied instead of imprisonment. Additional punishments, however, may be added.

18 Part 3, Section 228, Criminal Law LV, Chapter XX, Criminal Offences against General Safety and Public Order 19 Almost $80 \%$ of criminal offences initiated under Part 3, Section 228, were suspended, since the offender was not ascertained; for details see Table 2 below. 


\section{a46 :: AP Journal v.11 :: ARTICLE}

witnesses) due to the difficulty of proving the guilt of a particular person. ${ }^{20}$ The newly adopted norm on illegal acquisition and turnover of antiquities (in force since 1 January 2018) acts as a way around this, since it does not require direct evidence of desecration of a grave or looting of antiquities; the very fact of possessing antiquities is enough to apply the latter norm and prove the guilt of the offender.

The probable inconsistency of court-applied punishments based on Section 228, Part 3 should be pointed out. According to information provided by the LSC, there have been 8 judgments delivered based on the mentioned norm over the last 5 years. ${ }^{21}$ In 5 cases out of 8 , the criminal offence took place at actual (i.e. active) burial grounds. Only in one case was community service (amounting to 160) hours applied; for the looting of flower plants evaluated as having a value of EUR 50.22 In other cases, penalties ranged from 4 months and 20 days of imprisonment (for the looting of grave curbs evaluated at EUR 41523) up to 1 year of imprisonment (suspended sentence, for cutting off the branches of the grave hedge and digging out a bush ${ }^{24}$ ). In comparison, in cases where such offences were perpetrated at ancient burial grounds - as will be shown further in the case analysis part of this article - the most severe final punishment was a monetary fine in the amount of EUR 4300 without confiscation of property 25 (the total damage in the case was assessed by NCHB to amount to EUR 17,784.47) and 160 hours of community service for every convicted person in the group of three ${ }^{26}$ (the total damage in the case was assessed by NCHB to amount to EUR 3,235). ${ }^{27}$ Therefore, it may be concluded that desecration of active burial grounds is, in the opinion of the court, a more serious crime compared to the desecration of ancient burial grounds, even in cases where the latter caused damage to archaeological heritage and greater losses in monetary terms.

20 Less than $2 \%$ of criminal offences initiated under Part 3, Section 228, within the period of 2015-2019 were sent to prosecution; for details see Table 2 below.

213 cases out of these (archive Nos. K71-0249-18/25; KA05-0099-18/13; K08-0176-15) are discussed in detail below; by 07.08.2020, only 3 cases related to ancient burial grounds had been reviewed by the courts where criminal proceedings were initiated in 2015 or later (CA Information).

22 Archive No. K23-0145-17; Judgment as of 12 December 2017

23 Criminal case No. 11331053519, Archive No. K26-0687-19/2; Judgment as of 13 December 2019

24 Criminal case No. 11092056416, Archive No. K32-0447-16/8; Judgment as of 10 August 2016

25 Criminal case archive No. K71-0249-18/25; Criminal case archive No. KA05-0099-18/13

26 Criminal case archive No. K08-0176-15

27 It should also be noted that for the incriminated offence foreseen in Part 1, Section 228 (basic components of the offence, the desecration of graves evaluated at 50 EUR), the accused person was applied 200 hours of community works and material compensation of EUR 80 in one case (Criminal case No. 11261005417, Judgment as of 24 January 2017) and 80 hours of community works, material compensation of EUR 50 and moral compensation of EUR 500 in the other case (Criminal case No. 11096019816, archive No. K28-021216/3, Judgment as of 5 April 2016). 
Section 229: From the moment of adoption, the Criminal Law provided for liability for destruction or damaging of a cultural monument, (with up to 4 years of imprisonment for basic component elements of the offence, and up to 10 years if committed in a dangerous manner (e.g., arson, use of explosives). ${ }^{28}$ The norm has been amended several times, with the most recent wording being adopted in 2018, providing for liability for destruction, ${ }^{29}$ damaging ${ }^{30}$ or desecration $^{31}$ of a cultural monument protected by the State, illegal bringing out of the Republic of Latvia of a cultural monument protected by the State, or its illegal alienation, if this has resulted in substantial harm to the interests of the State or the public. Under the latest wording, these offences are considered less serious crimes, for which imprisonment for up to two years is provided for ${ }^{32}$ (while aggravation - destruction, damaging or desecration of a cultural monument protected by the State, if such has been committed by arson, use of explosives, or in another generally dangerous manner, or if it has been committed by a group of persons - is a serious crime with up to 5 years of imprisonment. ${ }^{33}$ It should be noted that if any aggravating element is present, no proof of the caused substantial harm is required).

As regards practical applicability of the norm, of 44 criminal offences and events registered during the period of 5 years (2015-2019), which were qualified under Part 1, Section 229, only two were ever sent for prosecution, with neither of these eventually reaching the court (IC statistics; CA statistics). ${ }^{34}$ For Part 2, Section 229 laggravation of the crime, where proof of substantial harm is no longer required), out of 3 registered criminal offences in the period 2015-2019, also two cases were sent to prosecution, again with neither of these eventually reaching

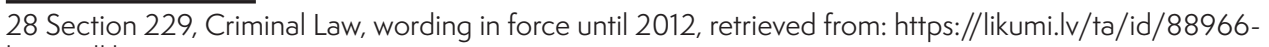
kriminallikums.

29 Destruction is the physical or mechanical action upon the object against which a criminal offence is committed, as a result of which it either ceases to exist completely as an object of the material world or becomes completely unfit for its purpose and can no longer be repaired or restored (Krastin,š, Liholaja, Hamkova, 2019, p.283).

30 Damaging is a change in the characteristics of the object against which a criminal offence is committed which significantly impairs or reduces its value (Krastinšs, Liholaja, Hamkova, 2019, p.283).

31 Desecration of cultural monuments can take the form of the excavation and destruction of archaeological sites, whether inside or outside a State-protected cultural monument, thus prohibiting the use of a particular place to explain the past, the placement of various offensive inscriptions and drawings on cultural monuments, and similar cynical, immoral acts (Krastin,š, Liholaja, Hamkova, 2019, p.283)

32 Criminal offences in Latvia are divided into criminal violations (deprivation of liberty from 15 days to 3 months) and crimes according to the nature and harm of the threat to the interests of a person or society. Crimes are divided as follows: less serious crimes (deprivation of liberty 3 months -3 years), serious crimes (deprivation of liberty 3 years -8 years) and especially serious crimes (deprivation of liberty 8 years - life imprisonment). For more details, see Section 7, Criminal Law.

33 Part 2, Section 229, Criminal Law

34 About $70 \%$ of registered criminal offences initiated under Part 1, Section 229 of the Criminal Law during the period 2015-2019 were suspended due to an inability to ascertain the offender; for details see Table 2 below. 


\section{a48 :: AP Journal v.11 :: ARTICLE}

the court. Therefore, in the period studied, there were no cases where a person was convicted of destruction, damaging or desecration of a cultural monument protected by the State, illegal bringing out of the Republic of Latvia of a cultural monument protected by the State, or its illegal alienation under Section 229, Criminal Law.

Two specific issues have to be discussed in analysing the applicability of the norm to the damage of archaeological sites: the need to prove criminal intent and the cause of substantial harm.

\section{Criminal intent}

Based on the wording of the Section, the actions by which a cultural monument is destroyed, damaged or desecrated must be deemed to be intentional, because the offender must be aware of the harmfulness of their actions, either wanting to cause significant harm through these, or by knowingly allowing such consequences to occur (Krastinšs, Liholaja, Hamkova, 2019, p.284). In other words, criminal intent to destroy the archaeological site (ancient burial ground, for instance) needs to be demonstrated and proved. However, not all cultural monuments (and this is especially the case for ancient burial grounds) are marked or delineated as such at their location, ${ }^{35}$ with this only happening in instances where the owner agrees to mark the particular place. A reluctance to mark cultural monuments as such is generally justified by an unwillingness to attract unnecessary interest from treasure hunters or general visitors (AHD Interview). A lack of visible boundaries or other markings therefore makes it more difficult to prove the criminal intent of the offender to destroy or cause damage to the ancient burial ground, while to a layperson they are poorly visible (if not entirely invisible) (please see Fig. 1).

\section{The concept of substantial harm}

Any of the illegal activities per se - destruction, damaging, desecration, illegal export or alienation of a cultural monument - is not enough alone to be classified as a criminal offence under Section 229 of the Criminal Law, but it must also be proven that certain (substantial) harm has been caused to the interests of the State or the public. A correct understanding of substantial harm is a prerequisite for establishing the composition of a criminal offence, and for delimiting a criminal offence from a tort, administrative or disciplinary violation (Hamkova, 2018). The qualification process must not only prove the existence of significant harm, but also a causal link between the act or omission and the harmful consequences.

35 This was also an argument of the accused in the court case No. K73-1745-19/22 described below. Any fences or signs signifying that the territory was state- or otherwise protected were absent (ZDC Case materials). 
:: Kairiss \& Olevska - Assessing endangerment of archaeological... :: a49

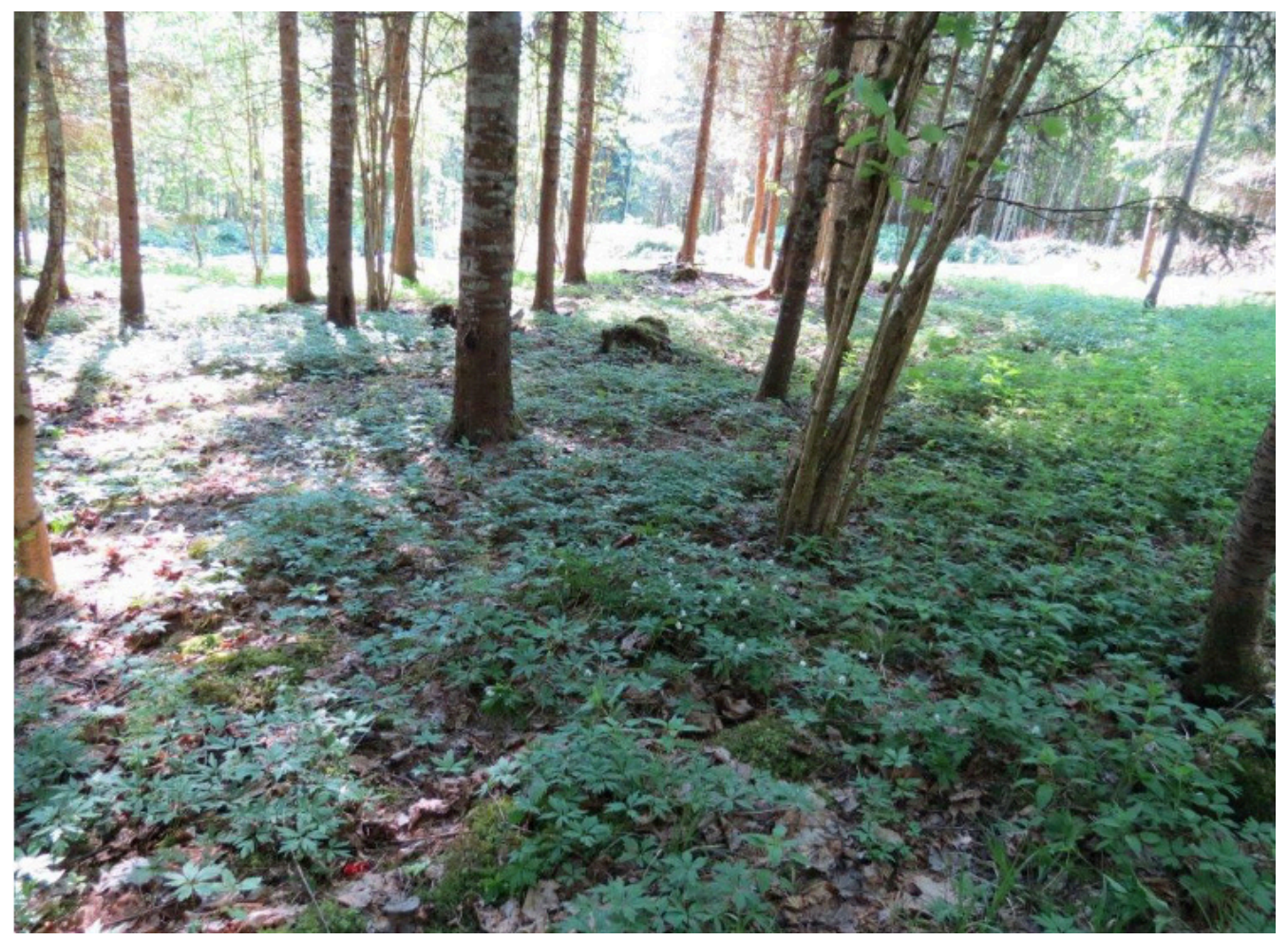

Fig. 1: Ancient cemetery in Alūksne municipality, Alsviki parish. (c) Courtesy of Digital Collection of Alūksne Museum.

Section 23 of The Criminal Law Enforcement Act provides definition of substantial harm caused by a criminal offence, which forms physical element lobjective aspect) of the offence. ${ }^{36}$ According to the Law, substantial harm shall be presumed if any of the following consequences have arisen:

1) The suffered property loss is equal to or exceeds five minimum monthly wages (i.e., 2150 EUR in 2020) ${ }^{37}$ and also other interests protected by law have been threatened. In order to apply this part of the norm, besides the losses measured in monetary terms in the specified amount, other endangered interests are to be additionally clarified, and the means of this endangerment shall be precisely elaborated (Krastin,š, Liholaja, Hamkova, 2019.; Hamkova, 2018).

2) The suffered property loss is equal to or exceeds ten minimum monthly wages (i.e., 4300 EUR in 2020). The mentioned monetary loss is in itself considered significant harm, and, if proved, no other evidence is required.

36 Section 23, Criminal Law Enforcement Act

37 The minimum monthly wage applied in Latvia is that which was in place at the time of committing a criminal offence; in 2020, the minimum monthly wage was EUR 430. 


\section{a50 :: AP Journal v.11 :: ARTICLE}

3) Other interests protected by law have been significantly threatened. Here it must be established that significant harm has been caused to at least one of the interests - State or public - individually (the sum of less significant damages caused to several interests is not applicable here). In order to apply this norm, an accusation cannot be limited to general wordings, vague statements, assumptions and references to well-known facts (Hamkova, 2018). When assessing whether the harm caused to the interests protected by law is substantial, it must be taken into account that the harm or threat thereto must be significant, and must be assessed in connection with the actual circumstances of the specific offence (Krastinšs, 2012; SC judgment SKK-190/2016). For substantial harm to be proved, the significance of the cultural monuments and therefore the need for and basis of the particular monument being protected by the State is to be clearly justified. An inability to adequately define the endangerment deprives the criminal offence of the opportunity to be qualified under the norm of destruction, damaging or desecration of a cultural monument in its basic composition (A) Interview). In this case the type (manifestation, nature) of the threat to the interests is important, as well as the severity of the threat to the interest, the nature of the act or omission, the characteristics of the interest carrier (i.e. endangered person) and the perception of the threat (Krastinšs, 2012; SC judgment SKK-190/2016).

According to the information provided by the police (SP Interview) and NCHB (AHD Interview), and the court cases analysed below, up until the middle of 2020 qualification of the offences had been based only on the monetary evaluation of the damage caused. ${ }^{38}$ Based on the above, no interests of stakeholders have ever been taken into consideration or mentioned in petitions for compensation, and the respective endangerment to State or public interests had never been reviewed by the court. Taking into account the small number of court cases, it is not possible to draw a conclusion on the level of difficulty involved in formulating the particular interest of the State or society, evaluating the substantiality thereof, and justifying the interests/losses caused thereto by the illegal actions of the offenders. However, it is apparent that, in cases where an archaeological site has been damaged, regardless of monetary assessment thereof, the concept of significant threat to the interests protected by law should be applied, since destruction or damaging of archaeological sites is always accompanied by harm to the archaeological heritage as a whole, often irrecoverably, therefore precluding the people and the State from acquisition of knowledge and preservation of history for current and future generations. ${ }^{39}$ This leads to the necessity of development of

38 According to Par.60, Cabinet Regulation 474, the NCHB shall prepare the materials related to the determination of damage caused to a cultural monument, if necessary, by inviting the relevant specialists and the owner (possessor) of the cultural monument, or the representatives thereof.

39 Representatives of the State Police and the Prosecutors' Office indicated that a more in-depth definition of 'substantial harm', as well as justification of the caused damage would facilitate greater efficiency of the 
pre-defined damage assessment criteria for such cases, which should be known to law enforcement agencies, prosecutors' offices and the courts.

Two new sections of Criminal Law came into force on 1 January 2018, providing special regulation for illegal actions involving state-owned antiquities ${ }^{40}$ and the release of a person from criminal liability for illegal acquisition, storage, movement, and transfer thereof. ${ }^{41}$ Each of these sections requires a more in-detail review.

Section 229.: According to this Section, illegal acquisition, ${ }^{42}$ storage ${ }^{43}$ movement, ${ }^{44}$ transfer, ${ }^{45}$ and alienation ${ }^{46}$ of State-owned antiquities or their illegal bringing out of the Republic of Latvia is subject to criminal liability by a sanction of deprivation of liberty for a period of up to one year or a lesser sentence (which makes it a lesser serious crime). State-owned antiquities (unless declared according to law) are antiquities found in archaeological sites in the ground, above the ground or in water dated until $17^{\text {th }}$ century included ${ }^{47}$.

According to the information provided by the State Police (SP Interview), acquisition, movement, transfer and alienation of antiquities request recording of a particular illegal activity during the process, otherwise an evidential basis alone is insufficient for the prosecutors' office to accept the case for prosecution. Even though the number of registered criminal offences under this criminal norm is comparatively high (9 overall in 2018-2019), meaning that the regulation as such is working, in practice only the activity of illicit storage has been incriminated during the mentioned period. This is due to the fact that storage, when compared to other illegal activities (e.g., transfer), is easier to prove (SP Interview). As a result, only four cases qualified under Section 229.' were sent for prosecution in 2019

respective criminal proceedings concerning archaeological heritage and make the work of investigative and prosecutorial institutions and courts more effective (SP Interview, PO Interview).

40 Section 229.!, Criminal Law

41 Section 229. ${ }^{\text {, }}$ Criminal Law

42 Acquisition of antiquities is the obtaining of antiquities in any form, including the excavation of archaeological antiquities without research and recording of context, in violation of the law, or so-called 'treasure-hunting' (illegal digging), which is considered the illegal acquisition of State-owned antiquities whether or not excavated from the territory of a State-protected cultural monument or in ancient burial grounds and hillforts outside it. (Krastiņš, Liholaja, Hamkova, 2019, p.286).

43 Storage of antiquities means their actual possession and their overt or covert keeping in a place known to that person (Krastinšs, Liholaja, Hamkova, 2019, p.287).

44 Movement of antiquities is the act of moving antiquities in a space by means of a vehicle or by any other means, such as carrying (Krastiňš, Liholaja, Hamkova, 2019, p.287).

45 Transfer of antiquities means the transfer of antiquities from one place to another by post, luggage or through a third party (Krastiňš, Liholaja, Hamkova, 2019, p.287).

46 Alienation of antiquities means any transfer thereof to another person by sale, gifting, exchange, pledge, donation, etc. (Krastinšs, Liholaja, Hamkova, 2019, p.287).

47 Part 4, Section 7, Protection Law 


\section{a52 :: AP Journal v.11 :: ARTICLE}

(zero in $2018^{48}$ ), with only two making their way to court, and only one having a verdict finally rendered (CA statistics). However, a general growing trend in case materials submitted for court review under Section 229.' can be observed. Thus, in the first half of 2020, three cases had already been submitted to the court, with one verdict rendered. ${ }^{49}$

Table 2. Registered criminal offences which concern/may concern archaeological sites/ antiquities (2015-2019), absolute numbers (Kairiss, 2020).

\begin{tabular}{|l|c|c|c|c|c|}
\hline \multirow{2}{*}{$\begin{array}{c}\text { Qualification of } \\
\text { the offence }\end{array}$} & $\begin{array}{c}\text { Registered } \\
\text { criminal } \\
\text { offences in } \\
\text { total }^{50}\end{array}$ & $\begin{array}{c}\text { Out of criminal proceedings initiated since } 2015 \\
\text { Suspended } \\
\text { criminal } \\
\text { proceedings }^{51}\end{array}$ & $\begin{array}{c}\text { Sent to } \\
\text { prosecution }^{52}\end{array}$ & $\begin{array}{c}\text { Cases } \\
\text { received } \\
\text { by courts }\end{array}$ & $\begin{array}{c}\text { Courts' } \\
\text { decisions } \\
\text { rendered }^{54}\end{array}$ \\
\hline Section 228, Part 35 & 352 & 279 & 7 & 7 & 7 \\
\hline Section 229, Part 1 & 44 & 31 & 2 & 0 & 0 \\
\hline Section 229, Part 2 & 3 & 1 & 2 & 0 & 0 \\
\hline Section 2291 & 9 & 0 & 4 & 2 & 1 \\
\hline (2018-2019) & 408 & 311 & 15 & 9 & 8 \\
\hline Total & & & & & \\
\hline
\end{tabular}

Section 229. ${ }^{2}$ in its turn provides for release of a person from criminal liability for illegal acquisition, storage or turnover of State-owned antiquities. This norm was added to the Criminal Law upon the proposition of the then-Minister of Justice for the last (third) reading, with no publicly available annotation or justification

48 See Table 2.

491 January 2020 - 6 August 2020, CA statistics

50 Public statistics of the Information Centre of the Ministry of Interior

51 Part 1, Section 400 of the Criminal Procedure Law states that if the necessary criminal procedural actions have been taken in criminal proceedings and ascertainment of the person who has committed the criminal offence has not been successful, an investigator may, with the consent of the supervising prosecutor, take a decision in the form of a resolution on suspension of criminal proceedings. The decision is not subject to appeal. Data source: IC information.

52 IC Information

53 CA Information. CA statistics do not include penal orders drawn up by prosecutors.

54 CA Information

55 Registered offences qualified under Part 3, Section 228 of the Criminal Law comprise of offences committed in both actual and ancient burial grounds; according to the State Police (SP Information) and court statistics (LCS Information), the majority of such offences concern actual burial grounds. No statistics are gathered separately for ancient burial grounds and/or cultural monuments and other burial grounds (IC Information). 
for the introduction of such a regulation (Amendments to Criminal Law). No case has ever been initiated under the norm, and respectively the norm has never been reviewed/implemented at any of the procedural phases of the criminal process.

It should also be noted that if the person is released from liability under one of the grounds mentioned in the Section, they are not automatically to be released from liability for other corresponding offences, e.g. for damaging the monument or property from which the antiquities originate (A) Interview).

\section{Offences qualified by several sections of the Criminal Law}

From the materials associated with criminal cases or court judgments in several cases it can be established that the committed criminal offence may be initially qualified by several sections of the Criminal Law, forming a so-called conceptual aggregation of criminal offences. ${ }^{56}$ Such a case arises, for example, if a person performs illegal excavations upon a cultural monument (damaging a cultural monument, Section 229 of the Criminal Law), in ancient burial grounds (desecrating a burial place, Section 228 of the Criminal Law) and acquires, stores, moves, transfers or performs other illegal activities with state-owned antiquities (Section 229. of the Criminal Law).

In practice, however, conceptual aggregation of criminal offences is not frequently applied in the pre-trial investigation process (Table 3), and persons are instead usually convicted under one Section. This may be due to the fact that in practice difficulties exist in linking criminal activities together and proving that they were committed by the same person (e.g., the fact of illegal possession of state-owned antiquities is relatively easy to establish and prove, but it is more difficult to link illegal storage of antiquities with their illegal acquisition at the relevant cultural monument (ancient burial ground)).

Table 3. Offences initially qualified by several sections of the Criminal Law (2015-2019)57

\begin{tabular}{|l|r|r|r|r|}
\hline Qualification of the offence & $\begin{array}{c}\text { Section 228, } \\
\text { Part 3 }\end{array}$ & $\begin{array}{c}\text { Section 229, } \\
\text { Part 1 }\end{array}$ & $\begin{array}{c}\text { Section 229, } \\
\text { Part 2 }\end{array}$ & $\begin{array}{c}\text { Section 2291 } \\
(2018-2019)\end{array}$ \\
\hline Section 228, Part 3 & 2 & 2 & 0 & 0 \\
\hline Section 229, Part 1 & 0 & 0 & 0 & 0 \\
\hline Section 229, Part 2 & 0 & 0 & 0 & 0 \\
\hline Section 2291 (2018-2019) & 0 & & \\
\hline
\end{tabular}

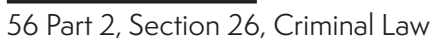

57 IC Information. This is the initial qualification in the pre-trial process; it is possible that within the process of prosecution and/or trial, re-qualification took place and the offence was re-qualified under one Section. 


\section{a54 :: AP Journal v.11 :: ARTICLE}

\section{Unauthorized economic activity on the territory of cultural monument}

The general regulation prohibits performance of any economic activity on territory of a cultural monument or its protection zone, unless permissions from the $\mathrm{NCHB}$ and the owner of the respective monuments are received. ${ }^{58}$ Nevertheless, the analysis shows that different types of economic activities are being performed upon the territory of poorly visible ancient burial grounds.

In a 2019 case before the ZDC, ${ }^{59}$ discussed below, the field (where a medieval cemetery was located) was periodically ploughed over an extended period of time. The deepest burials, however, according to the NCHB, were not affected as a result of ploughing (ZDC Case materials).

In a 2018 case before the VRC, the field (where the ancient cemetery was located) was used as sheep pasture, while unauthorized logging was carried out to the north of the ancient burial mound. The owner of the archaeological monument acknowledged that he knew about restrictions on performing logging activities due to the existence of the cemetery, but nevertheless decided to do it (VRC case materials). The NCHB concluded that substantial harm had not been caused to the cultural monument by the logging activity, however the activity itself was in violation of the law (VRC case materials).

While it is seen from the above cases that the NCHB was aware of the economic activity on the territories of the state-protected cultural monuments, it cannot be seen from the criminal case materials whether the possible negative impact of such activity and the amount thereof in material terms was ever evaluated by the land owner or state authorities, nor whether any administrative proceedings had been initiated on such grounds.

Although the situation requires further research, it can be assumed that some owners try to use the area of cultural monuments for unauthorized economic activities without realizing or taking into account the damage that such activi-

58 Section 3 of the Protection Law states that [...] immovable cultural monuments may be [...] modified only in an exceptional case with the permission of the NCHB.

Section 10 states that economic activity and any other type of activity in cultural monuments which may affect the preservation of cultural monuments [...] shall be permitted only with the consent of the owner of the cultural monument.

Section 19 provides that Cultural monuments shall, as a priority, be used for purposes of science, education and culture. Use of cultural monuments in economic activities shall be permitted only if such activity does not damage the monument, and does not reduce the historical, scientific and artistic value thereof.

Section 22 states that before commencing [...] economic activity the commissioning party thereof must ensure surveying of cultural values in the area of intended activity. Natural persons and legal persons who as a result of economic activity discover archaeological or other objects with cultural and historical value shall immediately notify the NCHB thereof, and further activity shall be suspended.

Section 23 states that [...] any activity within the protection zone of cultural monuments which affects the cultural and historical environment (for example, construction, artificial modification of terrain, forest management activity, retrieval of such previously unidentified objects which might have historical, scientific, artistic or other cultural value from the ground or water) may be performed only with the permission from the NCHB.

59 Judgment of ZDC as of 17 July 2019, case No. K73-1745-19/22 
ties may cause to the archaeological heritage. Presumably, the performance of unauthorized economic activities is based on a lack of understanding of the socio-economic value of the archaeological heritage, perception of the ownership of cultural monuments as an encumbrance, as well as insufficient explanatory work and control by the responsible institution.

\section{Damage assessment}

In criminal proceedings concerning archaeological sites, the State, which is usually represented by the NCHB, is recognized as the victim (or, at least, one of the victims). The analysis of court cases below shows that the NCHB claims only losses of (1) material value, and (2) scientific value of the damaged archaeological site within the criminal proceedings. The table below reflects the calculation methods used for the claimed losses:

Table 4. Types and monetary estimation of losses

\begin{tabular}{|c|l|l|}
\hline Type of loss & \multicolumn{1}{|c|}{ Basis for monetary estimation } & \multicolumn{1}{c|}{ Calculation method } \\
\hline Material value & $\begin{array}{l}\text { average insurance value of antique } \\
\text { collections found in analogous } \\
\text { cemeteries }\end{array}$ & $\begin{array}{l}\text { number of graves damaged } x \text { value } \\
\text { of one grave }\end{array}$ \\
\hline Scientific value & $\begin{array}{l}\text { scientific analysis of anthropological } \\
\text { material, i.e., morphological and } \\
\text { chemical analysis }\end{array}$ & $\begin{array}{l}\text { number of graves damaged } x \\
\text { analysis costs of anthropological } \\
\text { material of one grave }\end{array}$ \\
\hline
\end{tabular}

The material value of the grave inventory is comprised of the value of archaeological antiquities, discovering and identifying them in the context in accordance with the methodology of archaeological research, and then restoring and storing them in appropriate conditions (ZDC Case materials). According to para.59 of Cabinet Regulation 474, the cultural and historical value of a cultural monument is an assessment of a cultural monument, which includes the sum of the material, historical, scientific, cultural, aesthetic and market (international market of art and antique objects) value thereof. In Latvia, antiquities are excluded from civil circulation (except for duly declared antiquities ${ }^{60}$ ). Due to the absence of a relevant

60 Part 4, Section 7 of the Protection Law states that antiquities found in archaeological sites in the ground, above the ground or in water (dated until $17^{\text {th }}$ century inclusive) shall belong to the State, and they shall be stored by public museums. This provision shall not apply to antiquities on which the person has reported to the NCHB until 30 March 2013, as well as to antiquities the legal origin of which has been proved by the person after 30 March 2013 and has received a written certification from the NCHB thereon. 


\section{a56 :: AP Journal v.11 :: ARTICLE}

market, their market prices in Latvia cannot be determined (an approximate market price for antiquities can be determined, for example, from estimates and sales prices of auction houses located abroad, which legitimately sell the respective antiquities). Therefore, the insurance value is used to determine their financial value (ZDC Case materials; VDC/VRC Case materials). Information on the insurance value is provided by Latvian museums, which have collections of archaeological antiquities and which insure antiquities in the cases specified in regulatory enactments (VRC Case materials). There is no other methodology available to or used by museums to determine the value of a destroyed grave in an archaeological monument (ZDC case materials). So, the museum determines the value only for each item individually, and does not evaluate the grave as a whole.

In the criminal proceedings analysed, expenses for the research of material potentially obtained from the burial site (e.g., morphological and chemical analysis of anthropological material determining gender, age (if possible), as well as if any special features and/ or pathologies are visible) were taken as the basis for determining the loss of scientific value in monetary terms. The evaluation of anthropological material is the minimal extent of research performed by archaeologists when a new burial is discovered.

Other losses (e.g. expenses for inspection, documentation, emergency conservation of the archaeological site lat least burial, reburial of mortal remains, etc.), losses for further research/use of the archaeological site and loss of profit) were not included in calculations by the NCHB in the analysed criminal cases, and no compensation for such was claimed. This suggests that the actual losses in monetary terms in the reviewed criminal proceedings were greater than what was actually claimed. The above leads to the conclusion that, in order to make the investigation, prosecution and prosecution of criminal offences more efficient, the calculation of damages should be based on clearly defined, objective and known criteria for determining damage, to archaeological site owners, the NCHB, law enforcement, prosecutors and courts.

In the absence of such criteria, as is shown in the VRC judgment analysed below, it is hard for the judge to appraise the damage caused to an archaeological site. In the below case, the court arrived at the conclusion that the indictment did not show that the accused, through their actions of damaging a cultural monument, caused significant harm to the interests of the State or society, nor in which way this harm was manifested. Therefore, it decided to terminate criminal proceedings against the accused under Part 1, Section 229 of the Criminal Law (VRC Case materials). Consequently, the offender was eventually not charged with damaging a cultural monument, but rather only Part 3, Section 228 of the Criminal Law (desecration of graves). 
Besides, unassessed losses and unclaimed compensation for the emergency conservation of the archaeological site resolves in a later obligation of the owner at his/her own expense. The Protection Law states that conservation, maintenance, renovation and restoration of a cultural monument shall be performed by the owner (possessor) of the cultural monument at his or her own expense. ${ }^{61}$ However, in practice, if the owner is not guilty for the damage caused, the NCHB does not request emergency conservation from the owner, but rather engages specialists from the NCHB to perform the necessary activities within the capacity of the authority (AHD Answers). In certain cases, archaeologists, pupils and volunteers are engaged in these works, which may take place years after the damage was caused ([...] archaeologists, together with pupils and volunteers, [conducted] archaeological research in the ancient burial grounds of Login. Hillock cemetery is located in Vilaka region and four and a half years ago most of it was destroyed by illegal diggers (Lrtv.lv, 2019)).

\section{Analysis of criminal cases}

\section{Criminal case No. 11817006218; archive No. K73-1745-19}

Judgment of Zemgale District Court as of 17 July 2019, case No. K73-1745$19 / 22$

\section{Facts of the case}

In August 2018, the NCHB received an email stating that the online Latvian Collectors' Forum contained information about a YouTube video where a person was seen with a metal detector looking for and unearthing a medieval burial place. Based on the provided information, the NCHB identified and fixed damage done to the State-protected cultural monument of local significance; Klibju medieval cemetery. A subsequent inspection of the site found 61 pits, whose character was suggestive of a search for historical artefacts using a metal detector (ZDC Case materials), with 55 such pits being located upon the territory of the cultural monument and 6 within the protection zone (ZDC Case materials). The NCHB asked the State Police to initiate criminal proceedings based on Part 3, Section 228 (looting of objects in graves) and Part 1, Section 229 (damaging of state-protected cultural monument, if substantial harm has been caused) of the Criminal Law.

In October 2018, the State Police initiated criminal proceedings under Part 3, Section 228 (looting of objects in graves) and Section 229.' (storage of Stateowned antiquities) of the Criminal Law (ZDC Case materials); the NCHB was recognized as a victim (ZDC Case materials). 


\section{a58 :: AP Journal v.11 :: ARTICLE}

\section{Findings of relevance in the case materials:}

Damage assessment. Within the criminal proceedings, the NCHB applied for compensation of damages caused to cultural and historical value of the archaeological monument in the amount of at least EUR 21,675, comprising of loss of material value in monetary terms, i.e. EUR 18,105, and loss of scientific value, i.e. EUR 3,570.

1) Material value. It was concluded during the inspection that 51 graves were damaged by the 55 pits made on the territory of the cultural monument (the damages caused by digging on the territory of the protection zone of the cultural monument were not considered).

Taking into account the above, the $\mathrm{LNMH}^{62}$ stated that the lowest insurance value of one burial of the medieval cemetery in 2006 (the last time a chronologically comparable burial inventory was legally exported and therefore insured by the museum) was EUR 355, which was taken by NCHB as a basis for assessing material damage caused to the cemetery. ${ }^{63}$ Therefore, the total material value of the damage was calculated as a multiplication of the total number of burials damaged (51) and the value of one grave (EUR 355 per burial), giving an amount of EUR 18,105.

2) Scientific value. For a monetary assessment, the NCHB referred to information provided by ILHUL, where the costs of basic analysis for anthropological material of one grave are cited in the amount of EUR $70^{64}$ (ZDC Case materials). Therefore, the total loss of scientific value of the particular archaeological monument is EUR 70 per burial, multiplied by the total number of burials damaged (51), giving an amount of EUR 3,570.

Re-qualification of the offence. During the investigation, the offence was partially re-qualified from Part 3, Section 228 (looting of objects in graves) to Part 1, Section 229 (damaging of state-protected cultural monument, if substantial harm has been caused), with criminal proceedings later being in part terminated for Part 1, Section 229. Thus, finally, the offender was only charged with illegal possession (storage) of State-owned antiquities (Section 229., Criminal Law; ZDC Case materials). Taking into account the amount of initial compensation applied for by the NCHB (the victim), which exceeded the criteria of 10 minimal monthly wages (Part 2, Section 23, Criminal Law Enforcement Act), the grounds for re-classification and later in part termination of the proceedings for damage of a cultural monument remain unclear from the case materials.

62 The LNMH possesses the analogous objects in its collections.

63 It should be noted that the NCHB refers to the letter of the LNMH as of 2015, which in its turn refers to the insurance values of 2006, with no coefficients applied or other additional calculations provided.

64 It should be noted that the NCHB refers to the letter of the Historic Institute as of 2015, with no coefficients applied or other additional calculations provided. 
:: Kairiss \& Olevska - Assessing endangerment of archaeological... :: a59

Taking into account the fact that the proceedings were in part terminated for Part 1, Section 229 of the Criminal Law, the NCHB no longer maintained (i.e. withdrew) its request for compensation in the indicated amount for the pits dug in the Klibju Medieval Cemetery (ZDC Case materials);

Admission of guilt and punishment. The prosecution ended with an agreement for an admission of guilt and a punishment concluded between the prosecutor and the accused person, which was subsequently reviewed and approved in a written procedure by the court. According to the agreement (ZDC Case materials), the accused person admitted guilt of committing the alleged lesser serious crime - namely that they committed the illegal acquisition, transfer and possession (storage) of state-owned antiquities in the total amount of EUR 83965 - in full, thus committing a crime covered by Section 229.' of the Criminal Law. Additionally, this agreement documented the existing aggravating circumstance; i.e. that the criminal offence was committed out of a desire to acquire property. ${ }^{66}$

It is unclear from the case materials why the losses of material and scientific value calculated by the NCHB within the criminal proceedings were not taken into account. Even though it might be due to the re-qualification of the offence mentioned above, it seems that the damage caused by the offender was not redressed.

Final decision of the court. The prosecutor and the accused person agreed on the punishment - community service in the amount of 150 hours (ZDC Case materials). The court later approved the agreement bargain and associated punishment (ZDC Judgment).

\section{Criminal case No. 11817004716;}

Judgment of Vidzeme District Court as of 10 April 2018, case No. K710249-18/25

Judgment of Vidzeme Regional Court as of 13 December 2018, case No. KA05-0099-18/1367

\section{Facts of the case}

In July 2013, during the inspection of the State-protected archaeological monument of State significance - the Asari ancient burial ground - the $\mathrm{NCHB}^{68}$ fixed

65 According to the protocol of the NCHB's Archaeological Antiquities Evaluation Commission, the value of archaeological antiquities received for evaluation within criminal proceedings shall correspond to the insurance value which is determined by a commission from a specific state-accredited museum (ZDC Case materials). The LNMH evaluated 28 archaeological antiquities in question, evaluated at a total amount of EUR 839 (ZDC Case materials).

66 Par.11, Part 1, Section 48, Criminal Law

67 This is, as of August 2020, the only case that has ever been reviewed by the court of appeals under the criminal law norms concerning cultural heritage protection.

68 Until 2018 known as the State Inspection for Heritage Protection 


\section{a60 :: AP Journal v.11 :: ARTICLE}

damage caused by searching for and removing archaeological antiquities from the ancient burials with a metal detector (VDC/VRC Case materials).

State police initiated criminal proceedings under Section 229 (destruction and damaging of cultural monuments) and Section 228 (desecration of graves and corpses) of the Criminal Law ${ }^{69}$ (VDC/VRC Case materials).

According to the Judgement, ${ }^{70}$ the accused person was [for] more than 10 years engaged in collecting antiquities, which he dug out of the ground. He had also excavated antiquities in ancient cemeteries. He knew that digging in ancient cemeteries was forbidden; did not touch the excavated bone fragments, returning them back where he found them, but took only antiquities (VDC Judgment). The accused person had also traded antiquities on the internet from 2014 to 20 June 2016 (VDC Judgment).

\section{Findings of relevance in the case materials:}

Damage assessment. Within the criminal proceedings, the NCHB applied for compensation of damages caused to the cultural and historical value of the archaeological monument to the amount of at least EUR 17,784.4771 (VDC/VRC Case materials), comprising of loss of material value in monetary terms, i.e. EUR 14,918.81, and loss of scientific value, i.e. EUR 2,865.66. Justification for both types of values predominantly mirrors those analysed in the ZDC case above.

1) Material value. During the inspection, it was determined that the number of damaged burials corresponded to the number of pits and their size; a total of 6 damaged burials. The calculation of material value was based on the LNMH's letter as of $2013^{72}$ (VDC/VRC Case materials), equalling EUR 2,486.47 for one grave, which was taken by NCHB as a basis for calculating material damage caused to the cemetery. Therefore, the total material value of the damage was EUR 2,486.47 per grave (burial place) multiplied by the total number of burials damaged (6), giving a total amount of material damage of EUR 14,918.82.

2) Scientific value. The grounds of assessing damage caused to the scientific value of the archaeological monument is precisely the same as the

69 Wording of Sections as of 2016

70 With reference to interrogation file, VDC/VRC Case materials

71 The calculation was performed in October 2013, when the Latvian national currency was the Latvian lat (LVL). The total amount of damage was appraised at LVL 12,499.20 which was rounded down to LVL 12,499 and then exchanged into EUR at the fixed rate of 1:0.702804, thus totalling EUR 17,784.47. Further in the text, all sums will be correspondingly transposed into EUR for easier references.

72 According to the letter of the LNMH, the price of the objects was based on the insurance value of equivalent objects insured for exhibitions in Russia in 1999, Poland in 2007 and Latvia in 2012. No coefficients or other additional calculations were applied by the NCHB in reference to calculations for damage caused to scientific value in 2013 and later in 2016 (VDC/VRC Case materials) 
one in the ZDC judgment analysed above, except for the actual value of the analysis of the anthropological material from one burial place, which was taken as a cost of total analysis (as opposed to basic analysis), ${ }^{73}$ which, based on the information provided by ILHUL as of 2013, amounted to EUR $447.61^{74}$ (VDC/VRC Case materials). Therefore, the total loss of scientific value of the particular archaeological monument was given as EUR 447.61 per grave (burial place) multiplied by the total number of burials damaged (6), giving an amount of EUR 2,865.66.

At the court hearing, the representative of the NCHB stated that the actual damage was much larger; however, the amount claimed was limited to that which could be claimed based on the existing case materials (VDC/VRC Case materials).

Decision in the first instance. The court of first instance found the accused person guilty according to Part 3, Section 228 and Part 1, Section 229 of the Criminal Law, determining a final penalty of 280 hours of community service. The court also decided to recover in favour of the State the requested compensation in the amount of EUR 17,784.47. Material evidence (archaeological antiquities obtained from the particular cultural monument, from other places, and those that were not archaeological antiquities (i.e. $17^{\text {th }}$ century and earlier), as well as metal detectors) were to be confiscated.

Substance of appeal. The decision of the court of first instance was appealed by the lawyer of the accused in relation to the part of the sentence dealing with the material evidence. Objections to the appeal were submitted by the prosecutor and the NCHB (VRC Case materials), with both objecting to the return of the metal detectors.

Decision of the court of appeals. The court of appeals decided to reverse the judgment of the court of first instance insofar as it related to conviction pursuant to Part 3, Section 228 and Part 1, Section 229 of the Criminal Law, and to terminate criminal proceedings pursuant to Part 1, Section 229 of the Criminal Law. The judgment was also reversed insofar as it concerned the recovery of damages and as it decided on the action on evidence - archaeological antiquities and other artefacts dated to the $18^{\text {th }}$ century or earlier.

Termination of proceedings. The court terminated criminal proceedings against the accused under Part 1, Section 229 of the Criminal Law due to insufficient evidence of significant harm caused to the interests of the State or society.

73 It remains unclear from the case materials as to why the NCHB took the total cost of analysis of anthropological material in this case and only basic costs in ZDC case.

74 It should be noted that the NCHB refers to the letter of the LNMH as of 2013, with no coefficients applied or other additional calculations provided. 


\section{a62 :: AP Journal v.11 :: ARTICLE}

Recovery of damages. Given that the archaeological antiquities that the accused looted from the cultural monument were confiscated and transferred to the LNMH, the court of appeals acknowledged that the judgment in the first instance should be reversed and that no compensation could be awarded (VRC Case materials). Taking into account that the requested compensation comprised of two elements - lost material and scientific value - it is unclear from the judgment why at least the loss of scientific value was not to be awarded.

Return of material evidence. The court of appeals further stated that, due to the fact that the collection of items other than antiquities (i.e., dated to the $18^{\text {th }}$ century or earlier) in the Republic of Latvia is not forbidden by law, all such items were to be returned to the accused. It should be noted here that, according to Civil Law, those who search for concealed property on the land of another person, shall not acquire any of or anything from the concealed property they have found, and all such property shall accrue to the person who owns the land. ${ }^{75}$ In the cases analysed in the article, no claims were put forward by landowners regarding artefacts dated to the $18^{\text {th }}$ century or earlier found on their territory.

Final penalty. The court of appeals acknowledged that the accused was a person with a disability, who therefore, according to the Criminal Law, could not be punished with community service. Taking into account the above, the fact that the accused was finally incriminated only according to Part 3, Section 228 of the Criminal Law, and the fact that the court of second instance was unable to apply a more severe verdict for the accused and to apply imprisonment, the court finally applied a monetary fine in the amount of EUR 4,300, without confiscation of property (since there was nothing to confiscate from the accused) (VRC Judgment).

\section{Criminal Case No. 11100009615}

Judgment of Alüksne District Court (current title: Vidzeme District court (Alūksnē)) as of 30 November 2015, case No. K08-0176-1576

\section{Facts of the case}

The regional inspector of the NCHB received information from a police officer about digging activity at a location which later, upon inspection, appeared to fall within the protection zone of a State-protected cultural monument; Asaru ancient cemetery. The offenders used metal detectors. They were arrested at the site.

State Police initiated criminal proceedings according to Part 1, Section 229 of the Criminal Law.

76 The first case in the Republic of Latvia where a group of persons accused of Part 3, Section 228, Criminal Law for desecration of graves on the territory of state protected cultural monument received an actual penalty. 
:: Kairiss \& Olevska - Assessing endangerment of archaeological... :: ab3

\section{Findings of relevance in the case materials:}

Newly found cultural monument. Taking into account the specifics of archaeological ancient sites, the protection zones of archaeological and cultural monuments are determined taking into account the possibility of a substance of cultural and historical value in connection with the specific archaeological and cultural monument [...]. Thus, the destruction of archaeological ancient sites in the protection zone of an archaeological monument affects the cultural-historical value (composition) of a particular archaeological cultural monument (ADC Case materials). Based on the objects found in the protection zone of Asaru ancient cemetery, a State-protected cultural monument, the NCHB assigned the status of a newly-found cultural monument to the territory where the illegal activities took place, and subsequently gave a name to the ancient archaeological site: Asaru Ancient Cemetery II.

Re-qualification. Due to the fact that the site was not considered a State-protected cultural monument at the moment of commission of the crime, the offence was re-qualified from Part 1, Section 229 to Part 3, Section 228 of the Criminal Law.

Damage assessment. In this case, the NCHB evaluated the damages caused to the newly-found object - the ancient archaeological site Asaru Ancient Cemetery II - as corresponding to the monetary value of the archaeological objects found at the archaeological site, equalling EUR 3,23577 (ADC Case materials).

Decision of the court. All the three accused persons agreed to the extent and legal qualification of the offence committed, fully acknowledged their guilt of the criminal offence, signed an agreement regarding an admission of guilt and punishment with the prosecutor, being given 160 hours of community service each.

\section{Final remarks}

\section{Limitations}

The research conducted here has several limitations that should be taken into account. The main limitation relates to the lack of sufficient case law in Latvia that prevented the authors from undertaking a deeper analysis of the qualification aspects and effectiveness of assessment of substantial harm caused to archaeological monuments. According to the information available to the authors, this is the first research in Latvia dedicated to the applicability of Criminal Law norms regulating damage caused to archaeological sites. Therefore, there is an apparent lack of theoretical and practical foundation. Besides, Section 229.1 of the Criminal Law

77 The total value of the antiquities was based on the insurance value of equivalent antiquities in the LNMH's collections when they were transferred to the Moravian Museum (Moravské zemské muzeum) in the Czech Republic in 2013 (ARC Case Materials). 


\section{a64 :: AP Journal v.11 :: ARTICLE}

is a relatively new norm, so more time is required to test its effectiveness in cases of illegal actions involving State-owned antiquities.

\section{Conclusions and recommendations}

The Latvian legal framework concerning protection of archaeological heritage against damage and illegal acquisition of antiquities is generally aligned to the on-the-ground situation (in certain cases it is possible to initiate criminal proceedings, forward them for prosecution and trial), but practical implementation of the legal norms presents challenges. These challenges include qualification of offences simultaneously under several Sections of the Criminal Law (e.g., desecration of burials and illegal acquisition of antiquities), aspects of proof (e.g., illegal acquisition and/or transfer of antiques), damage assessment, and application of appropriate penalties.

The analysis of criminal case materials and case law shows that no objective criteria for assessing damage have been introduced, i.e. material value of the damage caused to ancient burial grounds has been calculated only as an average insurance value of antiquities typically found in analogous burial grounds, thus causing the following imperfections:

a) the value of antiquities typically found in analogous burial grounds is not determinative for all types of ancient burials, and value may therefore vary depending on the looted burial ground;

b) other losses (e.g., expenses for inspection, documentation, putting in order the archaeological site (at least burial, reburial of mortal remains, etc.), losses related to impossibility of further research/potential use of the archaeological site) are not calculated, and no compensation for these is claimed. Besides, it is not clear, for example, at whose expense the destruction caused to the archaeological site is to be remedied, and who is to put in order for this, while transferring this task to volunteers is unjust. This makes it possible to conclude that the actual monetary damage is greater than that determined and claimed in criminal proceedings;

c) no coefficients are applied to the insurance values of relatively old exhibitions.

Scientific value of the damage caused to ancient burial grounds has been calculated only in terms of the price of analysis of the anthropological material. It should be noted, however, that not only is anthropological material to be found in a grave, and therefore morphological and biochemical analyses do not reflect the whole value of the burial place. 
This indicates that, in order to objectively assess the caused damage in monetary terms, it is necessary to develop and implement damage assessment criteria. These criteria have to be available and explained to the NCHB, law enforcement agencies, the prosecutor's office and the courts. The issue of public availability of these criteria is also important.

The application of Section 229 of the Criminal Law (destruction or damaging of a cultural monument) is inextricably linked with the cause of significant damage to the interests of the State or society. However, the examination of the criminal case materials and the case law shows that the material damage suffered is not objectively or exhaustively justified, thus creating difficulties in the application of the Section itself. Cooperation between the NCHB, law enforcement agencies and the prosecutor's office (preferably also the courts) is needed in order to develop and implement basic criteria for establishing significant harm (in non-monetary terms) related to the destruction or damage of cultural monuments.

Approximately $70 \%$ of criminal proceedings initiated under Section 229 of the Criminal Law (destruction or damaging of a cultural monument) have been suspended under Section 400 of the Criminal Procedure Law due to the impossibility of identifying the offenders. At least in part, this may be caused by the delayed provision of information to law enforcement agencies about the caused damage to cultural monuments, which makes it difficult to identify the offenders. Increasing the awareness of the owners of cultural monuments about the need to report the detected damage as soon as possible, while simultaneously strengthening the monitoring of the territory, could lead to greater success in the investigation of the relevant criminal offences. Another important factor would be the higher priority afforded by law enforcement agencies to investigations of the relevant offences.

Statistics on the damage detected in archaeological sites show that the most endangered sites in Latvia are ancient burial grounds (Kairiss, 2020). Thus, it is reasonable to assume that a significant proportion, if not most, of the antiquities that are illegally acquired and stored come directly from illegal excavations in ancient burial grounds. This, combined with the study of court practice, allows to conclude that a significant proportion of offences against the archaeological heritage can be qualified according to several articles of the Criminal Law, if antiquities have been illegally acquired from cultural monuments (ancient burial grounds). Obviously, the solution to the issue relates to the clarification and proof of the circumstances of the illegal acquisition of antiquities. This can be achieved, at least in part, through appropriate training and awareness-raising among law enforcement agencies, prosecutors and the courts. 


\section{a66 :: AP Journal v.11 :: ARTICLE}

A study of case law shows that offences in actual (active) burial grounds are subject to more severe sanctions than offences in ancient burial grounds, although in both cases the desecration of burials (modern or ancient) is at stake. Besides, in the case of ancient burials, the material damage caused is frequently greater, with damage also being caused to scientific interest. Obviously, the solution is to raise awareness among law enforcement agencies, prosecutors and the courts.

One of the most important factors in preventing and combatting crimes against cultural heritage is inter-institutional cooperation and exchange of information. If, for example, controls over items delivered through the postal service were to be strengthened and law enforcement authorities were informed about prohibited items, proof of illegal activity related to the transfer of antiquities within the framework of Section 229.1 of the Criminal Law would be significantly facilitated. This indicates a current need for increasing the awareness of the institutions involved, as well as for providing training on relevant issues. Training and awareness-raising would allow inter alia the effective sharing of best national and foreign practice in the aspects of cultural heritage protection (including criminal law).

The facts that indicate unauthorized long-term economic activity in the territory of archaeological monuments reflect on the one hand the ignorance or lack of information of the owners of cultural monuments, while on the other the possible insufficient monitoring of the situation by the responsible institutions. Owners of land (cultural monuments) may be in a difficult economic situation, so they want to broaden their economic activities as much as possible. It is likely that this situation cannot be effectively addressed through bans and restrictions alone, and so a dialogue needs to be developed between landowners, responsible public authorities and municipalities, in order to provide appropriate support to landowners and prevent unauthorized economic activities from affecting archaeological sites. It is important that the landowners' perception of archaeological monuments on their land is changed from that of a burden or hindrance to economic activity to one of socio-economic opportunity provided by such monuments.

Offences against cultural heritage pose a significant threat to the public interest, not only from a legal and cultural-historical point of view, but also from a socio-economic point of view. If a castle mound is destroyed, it does not mean that only a specific castle mound or its direct owner has suffered, as various interests of stakeholders at the local, regional, and even national and global levels may be affected. These interests can encompass not only economic (e.g., attracting tourists), but also social, symbolic, environmental and other aspects (Kairiss, 2020; Kairiss, Olevska, 2020). An analysis of the case law shows that, at present, compensation covers only material or scientific damage caused to a specific archaeological site, but the range of interests affected is wider. In view of the above, 
:: Kairiss \& Olevska - Assessing endangerment of archaeological... :: a67

further research should be carried out, with the aim of extending the concept of serious harm caused by criminal offences to difficult-to-quantify but important socio-economic interests.

\section{Abbreviations used}

Latvian Administrative Violations Code

AHD Interview

AHD Answers

AJ Interview

Amendments to

Criminal Law

Annotation 2014

AR

ADC

CA Information

Cabinet Regulation 241

Cabinet Regulation 474

Cabinet Regulation 916

Civil Law

Civil Procedure Law

Criminal Law
Latvian Administrative Violations Code of the Republic of Latvia

Interview with the Head of Archaeological and Historic department of the NCHB

Written answers submitted by the Head of Archaeological and Historic department of the NCHB

Interview with Andrejs Judins, the Head of Criminal Law Policy Subcommittee of the Legal Committee of the Saeima (Parliament of the Republic of Latvia) from 11.12.2018

Draft law "Amendments to the Criminal Law" addressed to the Parliament Presidium, as of 1 June 2017

Preliminary Impact Assessment Report of the Draft Law "Administrative Violations Procedure Law" of 2014

Annual work report of the State Inspection for Heritage Protection (from 2018 the National Cultural Heritage Board)

Vidzeme District Court (Alūksnē) (Former title: Alūksne District Court), criminal case No. 11100009615, judgement in case No. K08-0176-15

Information received from the Court Administration

Cabinet Regulation No. 241 adopted 29 April 2003 "ByLaw of the Ministry of Culture"

Cabinet Regulation No. 474 adopted 26 August 2003

"Regulations Regarding the Registration, Protection, Utilisation and Restoration of Cultural Monuments and the Granting of the Status of an Environment-Degrading Object"

Cabinet Regulation No. 916 adopted 9 November 2004 "By-law of the National Cultural Heritage Board"

Civil Law of the Republic of Latvia

Civil Procedure Law of the Republic of Latvia

Criminal Law of the Republic of Latvia 


\section{a68 :: AP Journal v.11 :: ARTICLE}

Criminal Law

Enforcement Act

Criminal Procedure

Law

IC Information

IC statistics

ILHUL

Law on Administrative liability

LCS Information

LNMH

$\mathrm{NCHB}$

NCHB statistics

PO Interview

SPCMR

SP Information

SP Interview

Protection Law

VDC

VRC

ZDC
Law On the Procedures for the Coming into Force and Application of The Criminal Law of the Republic of Latvia

Criminal Procedure Law of the Republic of Latvia

Information received from the Information Centre of the Ministry of Interior

Criminal statistics of the Information Centre of the Ministry of Interior

Institute of Latvian History at the University of Latvia

Law on Administrative Liability of the Republic of Latvia

Official information of the Latvian Court System available at manas.tiesas.lv

Latvian National Museum of History

National Cultural Heritage Board of the Republic of Latvia

Information received from the $\mathrm{NCHB}$

Interview with a prosecutor from the Prosecutor's Office of the Republic of Latvia

State Protected Cultural Monuments Register

Statistical Information submitted by the State Police

Interview with inspectors of the 2nd Department (combatting property crimes) of the Criminal Investigation Board, of Main Criminal Police Board of the State Police

Law of the Republic of Latvia on Protection of Cultural Monuments

Vidzeme District Court (Alūksnē), criminal case No.

11817004716, judgement in case No. K71-0249-18/25

Vidzeme Regional Court

Zemgale District Court (Bauskā)

\section{References}

Andris Kairiss, 2017, Awareness Raising and Protection of Archaeological Heritage Culture Crossroads, vol. 11. http://www.culturecrossroads.lv/pdf/233/en (accessed 6 September 2020)

Andris Kairiss, 2020, Latvijas arheoloǵiskā mantojuma aizsardzības un sociāli-ekonomiskās attīstības faktori (Factors of Protection and Socio-Economic 
:: Kairiss \& Olevska - Assessing endangerment of archaeological... :: a69

Development of Latvia's Archaeological Heritage), Latvijas Zinātṇu Akadēmijas Vēstis. A dalı:a: Humanitārās un sociālās zinātnes, No. 3, 2020, retrieved from: http://www.lasproceedings.lv/publikacija/latvijas-arheologiska-mantojuma-aizsardzibas-un-sociali-ekonomiskas-attistibas-faktori/ (accessed 16 November 2020)

Andris Kairiss, Irina Olevska, 2020, Damage to Archaeological Sites: Assessment Criteria and Situation in Latvia, Baltic Journal of Real Estate Economics and Construction Management, 8, 45-82 https://doi.org/10.2478/ bjreecm-2020-0005

Andris Kairiss, Alise Šulte, Sandra Zirne, Egita Lūsēna, Juris T. Urtāns, Catalogue of Endangered Latvian Archaeological Artefacts, Rīga: Latvijas Kultūras akadēmija, 2016, retrieved from: https://www.interpol.int/Crimes/Cultural-heritage-crime/Protecting-cultural-heritage, https://lka.edu.lv/lv/petnieciba/ petijumu-projekti/akademiskie-petijumu-projekti/, https://www.nkmp.gov.lv/ Iv/pieejams-elektronisks-apdraudeto-latvijas-arheologisko-senlietu-katalogs (accessed 16 November 2020)

Criminal statistics of the Information Centre of the Ministry of Interior, 2011-2019, retrieved from: https://www.ic.iem.gov.lv/lv/kriminala-statistika laccessed 6 September 2020)

IR, Latvija - kapu aplaupītaju "lielvalsts", 21 July 2016, retrieved from: https:// ir.lv/2016/07/21/zurnals-latvija-kapu-aplaupitaju-lielvalsts/ (in Latvian; accessed 6 September 2020)

Kalvis Torgāns, 2006, Saistību tiesỉbas. I dala. Mācību grāmata, Rīga, Tiesu namu aǵentūra, 2006

LETA, 13 January 2019, Ar valsts atbalstu sakopts mantraču izpostītais Latgallu uzkalninu kapulauks Ciblas novadā, retrieved from: https://www.la.lv/ar-valsts-atbalstu-sakopts-mantracu-izpostitais-latgalu-uzkalninu-kapulauks-ciblas-novada (accessed 6 September 2020)

Lrtv.lv, 2019, Veic izpostîto Loginu senkapu arheoloǵisko izpēti, 05 September 2019. Retrieved from: http://www.Irtv.lv/zinas/veic-izpostito-loginu-senkapu-arheologisko-izpeti-8516 (accessed 6 September 2020)

National Cultural Heritage Board, 30 April 2020, Reminder about restrictions on the use of metal detectors (in Latvian), retrieved from: https://www.nkmp.gov. $\mathrm{lv} / \mathrm{lv} /$ jaunums/atgadinajums-par-metala-detektoru-lietosanas-ierobezojumiem (accessed 16 November 2020)

Preliminary Impact Assessment Report of the Draft Law "Administrative Violations Procedure Law" (annotation), 2014, retrieved from: https://titania.saeima.lv/ LIVS12/SaeimaLIVS12.nsf/0/8F85FC1AE272C759C2257D8E004788AD?OpenDocument 


\section{a70 :: AP Journal v.11 :: ARTICLE}

Uldis Krastinšš, Vērtējuma jēdzieni Krimināllikuma normās. Jurista vārds, No. 24, 12 June 2012

Uldis Krastin,š, Valentija Liholaja, Diāna Hamkova, 2019, Krimināllikuma komentāri. Trešā dąla (XVIII-XXV nodaląa), Tiesu Namu aǵentūra

UNESCO, 26 June 2020, UNESCO expert meeting on illegal excavations and online trade during COVID-19, retrieved from: https://en.unesco. org/news/26-june-unesco-expert-meeting-illegal-excavations-and-online-trade-during-covid-19

\section{Legal acts}

Cabinet Regulation No. 241 adopted 29 April 2003 "By-Law of the Ministry of Culture", retrieved from: https://likumi.lv/ta/en/en/id/74750-by-law-of-theministry-of-culture (accessed 6 September 2020)

Cabinet Regulation No. 474 as of 26 August 2003, Regulations Regarding the Registration, Protection, Utilisation and Restoration of Cultural Monuments and the Granting of the Status of an Environment-Degrading Object, retrieved from https:/likumi.lv/ta/en/en/id/78458-regulations-regarding-the-registration-protection-utilisation-and-restoration-of-cultural-monuments-and-the-granting-of-the-status-of-an-environment-degrading-object (accessed 6 September 2020)

Cabinet Regulation No. 916 adopted 9 November 2004 "By-law of the National Cultural Heritage Board", retrieved from: https:/likumi.lv/ta/en/en/id/96371-bylaw-of-the-state-inspection-for-heritage-protection (accessed 6 September 2020)

Civil Law of the Republic of Latvia, as of 1937, retrieved from: https://likumi.lv/ta/ en/en/id/225418-the-civil-law (accessed 6 September 2020)

Criminal Procedure Law of the Republic of Latvia, as of 2005, retrieved from: https://likumi.lv/ta/en/en/id/107820-criminal-procedure-law laccessed 6 September 2020)

Draft law "Amendments to Criminal Law" addressed to Parliament Presidium, as of 1 June 2017, retrieved from: https://titania.saeima.lv/LIVS12/SaeimaLIVS12. nsf/0/C2A0CCBD12A76915C2258132002631B1?OpenDocument laccessed 6 September 2020)

Latvian Administrative Violations Code of the Republic of Latvia, as of 1985, retrieved from: https://likumi.lv/ta/en/en/id/89648-latvian-administrative-violations-code (accessed 6 September 2020)

Law of the Republic of Latvia On Protection of Cultural Monuments, as of 12.02.1992., retrieved from https://likumi.lv/ta/en/en/id/72551-on-protection-of-cultural-monuments (accessed 6 September 2020) 
:: Kairiss \& Olevska - Assessing endangerment of archaeological... :: a71

Law on Administrative Liability of the Republic of Latvia, as of 2020, retrieved from https://likumi.lv/ta/en/en/id/303007-law-on-administrative-liability laccessed 6 September 2020)

Law on the procedures for the coming into force and application of the criminal law as of 1998, retrieved from: https://likumi.lv/ta/en/en/id/50539-on-theprocedures-for-the-coming-into-force-and-application-of-the-criminal-law laccessed 6 September 2020)

\section{Annual work reports of the NCHB}

Annual work report of 2016 of State Inspection for Heritage Protection (from 2018 National Cultural Heritage Board), retrieved from: https://www.nkmp. gov.lv/lv/publiskie-parskati (accessed 16 November 2020)

Annual work report of 2017 of State Inspection for Heritage Protection (from 2018 National Cultural Heritage Board), retrieved from: https://www.nkmp. gov.lv/lv/publiskie-parskati (accessed 16 November 2020)

Annual work report of 2018 of National Cultural Heritage Board, retrieved from: https://www.nkmp.gov.lv/lv/publiskie-parskati (accessed 16 November 2020)

\section{Criminal case materials}

Liepāja Court, judgment, case No. K20-0245-17, as of 24 January 2017, retrieved from: https://manas.tiesas.lv/eTiesasMvc/nolemumi

Supreme Court of the Republic of Latvia, decision, Case No. SKK-190/2016, as of 29 September 2016

Vidzeme District Court (Alūksnē), judgement, case No. K08-0176-15, as of 30 November 2015, retrieved from: https://manas.tiesas.lv/eTiesasMvc/nolemumi

Vidzeme District Court (Alūksnē), materials of criminal case No. 11100009615

Vidzeme District Court (Alūksnē), judgement, case No. K71-0249-18/25, as of 10 April 2018, retrieved from: https://manas.tiesas.Iv/eTiesasMvc/nolemumi

Vidzeme Regional Court, Vidzeme District Court (Alūksnē), materials of criminal case No. 11817004716

Vidzeme Regional Court, judgement, case No. KA05-0099-18/13, as of 13 December 2018, retrieved from: https://manas.tiesas.lv/eTiesasMvc/nolemumi

Zemgale District Court (Bauskā), judgment, case No. K73-1745-19/22, as of 17 July 2019, retrieved from: https://manas.tiesas.Iv/eTiesasMvc/nolemumi

Zemgale District Court (Bauskā), materials of criminal case No. 11817006218 


\section{a72 :: AP Journal v.11 :: ARTICLE}

\section{Information provided on request}

Information received from the Information Centre of the Ministry of Interior upon request of Andris Kairiss in July-August 2020

Information received from the NCHB on 20 July 2020 upon request of Andris Kairiss

Information received from the Court Administration upon request of Irina Olevska on 7 August 2020

Interview with inspectors of $2^{\text {nd }}$ department (combatting property crimes) of the Criminal Investigation Board, of the Main Criminal Police Board of the State Police, interviewed for the article by Andris Kairiss, Irina Olevska on 22 July 2020

Interview with the Head of the Archaeological and Historic department of the $\mathrm{NCHB}$, interviewed for the article by Andris Kairiss, Irina Olevska on 29 July 2020

National Cultural Heritage Board, letter No. 05-01/3285 as of 20 July 2020. Data provided based on data request of Andris Kairiss

Prosecutor from the Prosecutors Office of the Republic of Latvia, interviewed by Andris Kairiss on 21 August 2020

Statistical Information submitted by the State Police on 24 July 2020 upon request of Andris Kairiss

Written answers submitted by the Head of Archaeological and Historic department of NCHB on 5 August 2020 upon request of the authors of the article 